\title{
Case Report: Accidental Death Due to Autoerotic Asphyxia Coupled With Fetishistic Transvestism
}

\author{
Mahesh Chand Meena ${ }^{1^{*}}$, Saloni Chadha ${ }^{1}$
}

1. Department of Forensic Medicine, Dr. Baba Sahib Ambedkar Medical College, Guru Gobind Singh Indraprastha University, Delhi, India.

\begin{tabular}{|l|l|}
\hline $\begin{array}{l}\text { Use your devic to scan } \\
\text { and read the article online }\end{array}$ & $\begin{array}{l}\text { dttation: Chand Meena M, Chadha S. Accidental Death Due to Autoerotic Asphyxia Coupled With Fetishistic Transvestism. In- } \\
\text { ternational Journal of Medical Toxicology \& Forensic Medicine. 2017; 7(3):189-193. https://doi.org/10.18869/nirp.ijmtfm.7.3.189 }\end{array}$ \\
doi: $:$ https://doi.org/10.18869/nirp.ijmtfm.7.3.189
\end{tabular}

Article info:

Received: 07 Jan. 2017

Accepted: 12 May 2017

\section{Keywords:}

Fetishism, Psychosis, Transvestism, Autoerotic asphyxia

\begin{abstract}
A B S T R A C T
Fetishistic transvestism is a disorder of sexual perversion associated with fantasies and sexual urges to dress in opposite gender clothing as a means of arousal and adjunct to masturbation and coitus. However, transvestism has been described in schizophrenia and psychosis and fetishism in the course of simple schizophrenia. Our reported case is a 26 year-old male found hanging in transvestite attire wearing blouse and petticoat. There was no psychiatric background and no known previous suicidal behavior of the deceased. The manner of death was finally considered to be an accident. The cause of the death was accidental hanging provoked by fatal autoerotic asphyxia.
\end{abstract}

\section{Introduction}

utoerotic asphyxia (hypoxyphilia) is a 1 paraphilia and subcategory of sexual masochism characterized by self-strangulation up to the point of loss of consciousness to enhance sexual arousal. This paraphilia is not common enough to be included as a separate paraphilia within the latest editions of the Diagnostic and Statistic Manual of Mental Disorders (DSM-IV) and International Statistical Classification of Diseases and Related Health Problems (ICD-10). Therefore, it is coded as paraphilia (deviatio sexualis) not otherwise specified [1-3]. However, it is an accidental lethal sexual practice in which hypoxia (reduced oxygen supply to tissue, in this case brain), is used to enhance orgasm by strangulation, hanging, suffocation/ exclusion of oxygen with plastic bags [4-8].
The decedent may or may not be engaged in manual masturbation during fatal auto erotic activity.

Autoerotic asphyxia is frequently accompanied with other paraphilias such as transvestism and bondage, and a great range of paraphernalia (props and devices involved in paraphilia sexual activities), sexual aids or pain-stimulating agents, pornographic magazines, intimate feminine garments, ropes, bondage, locks, chains, condoms, rubber items, and chemical anaesthetics [8]. Transvestism is described as the art of cross dressing in which opposite sex clothes are worn for sexual arousal, seen in both the sexes and most common in men. There are two types of transvestite; heterosexual group and homosexual tendencies group.

The heterosexual male transvestite wears conventional female clothing and unresolved problems in his marriage

\section{* Corresponding Author:}

Mahesh Chand Meena, MD

Address: Department of Forensic Medicine, Dr. Baba Sahib Ambedkar Medical College, Guru Gobind Singh Indraprastha University, Delhi, India. Tel: +91 (986) 8807888

E-mail:drmaheshchandmeena@gmail.com 
or other heterosexual relationships are often evident. The homosexual male transvestite, often wear clothes which are satirizing and impersonate, caricature, and mock women [9]. Anal self-stimulation with dildos, etc., and self-observation with mirrors or cameras are correlated with transvestism [10]. Older asphyxiators are now more likely to be engaged in bondage or transvestism, suggesting an elaboration of the ritual over time [4].

In French classical literature, Jean Giono described the practice of autoerotic asphyxiation in the 19th century among French mountain people, who used a leather cowl [11]. The sexual asphyxia is almost exclusively created by men; only a few reports exist concerning women [1216]. Male subjects are usually found using complex apparatus tend to create a complex environment, whereas female subjects are usually found naked with only a ligature around the neck [12]. This case report supports the creation of outrageous and appalling complex sexual scenes by male subjects. In this case, consideration of the death scene is important to understand the motive of the behavior of the young decedent, also it indicates past autoerotic activities.

\section{Materials and Methods}

In central Delhi a 26 years-old male servant was found dead in the servant quarter, which was locked from inside. The deceased lived with his owner, who had discovered him dead in the servant room, after returning from a relative's marriage. The victim was alone as the owner had been out of station for two days for attending marriage. The body was found hanging by a towel tied around the neck, standing on the upper part of the divan. The divan was situated under a beam, to which the towel was fastened. The body was found in an upright position in front of the mirror. He wore the blouse of the owner's wife, petticoat, and female undergarments (Figures 1 and 2). There were no pornographic pictures close to the body.

At autopsy, on external examination, it was a body of an adult male moderately built and well nourished. He was in transvestite attire wearing blouse, petticoat, and ladies undergarment. Rigor mortis was present partly in the upper limbs and well marked in lower limbs. Post mortem lividity was fixed over back of the trunk. Subconjunctival haemorrhage was noted with petechial haemorrhages around the eyes. Nail beds were bluish discoloured. Autopsy revealed ligature abrasions around the victim's neck. Ligature marks were located on the anterior part of the neck (Figure 3). The groove was very faint. Facial petechial haemorrhages were present. Dried seminal fluid was present around glans penis and inner aspect of thigh. On internal examination, mucosa of larynx was congested with intact hyoid bone (Figure 4), and petechial haemorrhages were present over pleura and epicardium. Pulmonary oedema was present in the lungs. There was no fracture of the hyoid bone or thyroid cartilage and no deep muscle bruises of the neck. Generalized visceral congestion was noted. Stomach contained semi-digested unrecognized food particles $(250 \mathrm{ml})$; no other significant autopsy findings were present.

There was no psychiatric background and no known previous suicidal behavior of the deceased. The manner of death was finally considered to be an accident. The cause of the death was accidental hanging provoked by fatal autoerotic asphyxia.

\section{Discussion}

Asphyxiophilia has been defined as the desire for a state of oxygen deficiency to elicit or enhance sexual excitement and orgasm [17]. The basic mechanism of sexual asphyxias is the production of cerebral hypoxia, which in some men appears to produce hallucinations of an erotic nature. This hypoxia is most often achieved by constriction of the neck by a ligature (a rope, in the case reported here). Forensic cases are numerous, and the literature contains some reports. De Sade's Justine describes sexual asphyxiation, and other authors have described sexual perversion associated with hanging

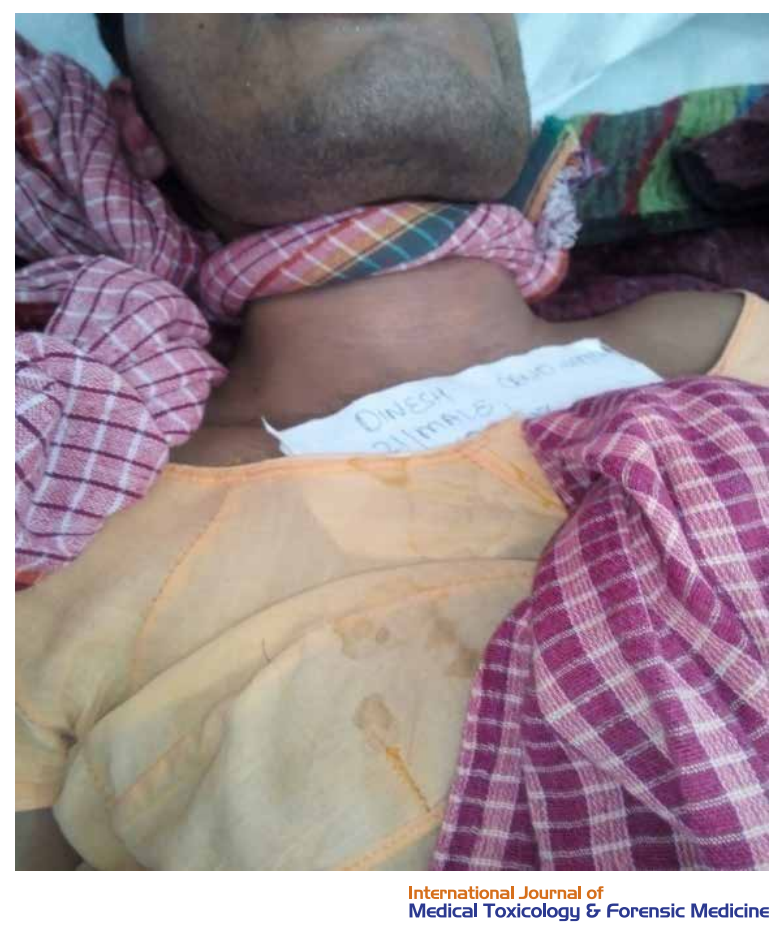

Figure 1. Ligature material in situ with wearing blouse 


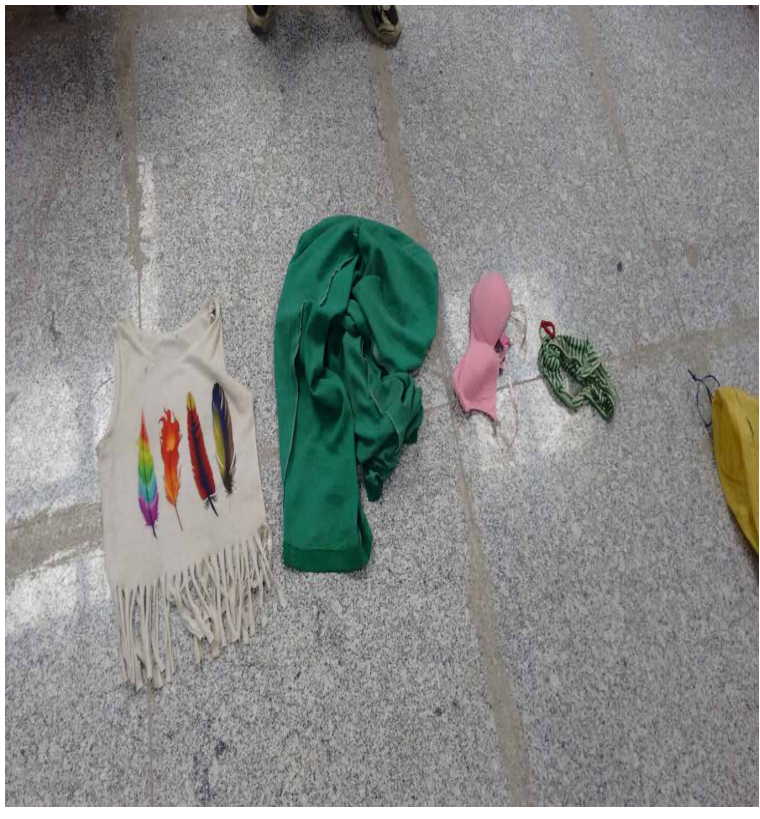

International Journal of

Figure 2. Clothes worn by deceased (petticoat \& undergarments)

[18]. The Eskimos have been known to perform sexual asphyxiation as a form of solitary or group activity [19].

Autoerotic deaths can be classified into typical and atypical depending on the presence or absence of accompanying non-lethal paraphilia. Lethal paraphilia may be in the form of compression around the neck, plastic bag asphyxia, restrictive bondage, chest compression, inhalation of volatile substances, insertion of objects in genitals, and stimulation of genitals by low voltage electricity. Whereas non lethal paraphilia are transvestism, fetishism, usage of mirror, pornography, etc. An autoerotic death may be diagnosed if it is solitary, accidental, and caused by any lethal paraphilia [9]. The most frequently encountered method of typical autoerotic activity is asphyxia by hanging or ligature [10].

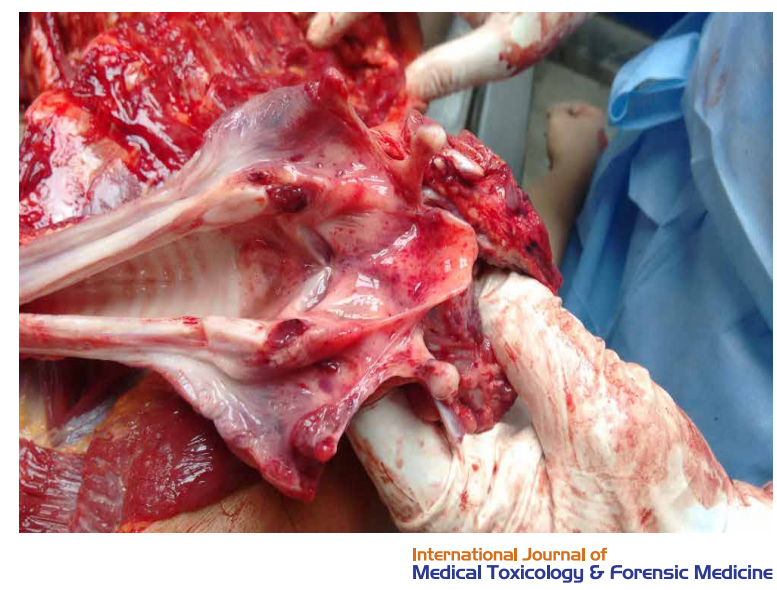

Figure 4. Intact hyoid bone with congestion in larynx

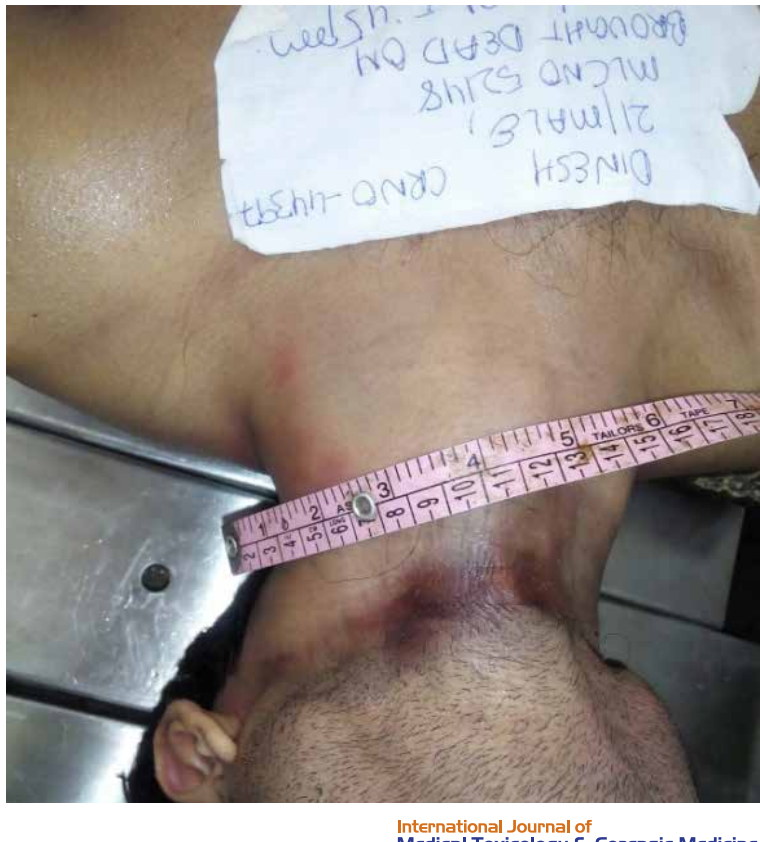

Medical Toxicology \& forensic Medicine

Figure 3. Ligature mark (pressure abrasion) over neck

Anal self-stimulation points to both masochism (passive pole of subjugation-humiliation axis determined by powerful fantasies deriving from poorly compensated fears of injury and reactive narcissistic rage) and identification with female sexual experience (inwardly oriented and permeated by visceral sensations).

Dynamically, cross-dressing serves two functions: expressing feminine identification and triumph over it. Both of them were strikingly present in the death scene. Volatile substance abuse and autoerotic behavior are distinct phenomenon. Still considerable overlap is found in $8 \%$ of cases reported by Anderson HR [20]. Autoerotic deaths in transvestite are reported in young males [21, 22].

In the present case, hanging was accidental and not suicidal. He was in a classic position, with an incomplete hanging. A vagal uneasiness was probably the starting point of a loss of consciousness. Asphyxia was secondary to the vagal uneasiness. On the other hand, toxicology analysis provided no evidence to support an incapacitating influence of intoxication with alcohol and/ or drugs. However, the finding of sperm on the clothes of a deceased, as in our case, is not reliable proof that ejaculation was achieved while the deceased was still alive. All investigations - death scene, external examination, context, autopsy findings - resulted in a conclusion of accidental hanging provoking fatal autoerotic asphyxia

Transvestism though has been described in schizophrenia and psychosis and fetishism has been described 
in the course of simple schizophrenia. In some men this appears to produce a "hypoxic high" or orgasm-like reaction accompanied by dizziness, shivering, palpitation, breathlessness, pain, hallucinations of an erotic nature, or even ejaculation as reported in some cases [23, 24].

In the present case, homicide seemed unlikely considering there were no evidence of a third party in the death such as disturbance in the house or forced entry other than that affected by the house owner, and there were no defence type injuries. Death circumstances such as isolation, timing, precaution against discovery and active preparation were more likely to be for providing a secure environment for pleasuring rather than for the purpose of suicide.

While periodically reported in newspapers, enormity of deaths due to autoerotic deaths, particularly in sexually perverts like in transvestism is highly unaddressed. There are several limitations in the data concerning autoerotic asphyxiation. Difficulty in ascertaining the number of practitioners of asphyxiophilia due to the social stigma, lack of statistics available in the Indian literature, hiding the evidence of asphyxiophilic deaths often by relatives due to the negative societal perception, and finally lack of any specific category in the ICD codes for deaths by sexual asphyxiation. Hence, these deaths may be misclassified as accidents, suicides, or homicides. As a result, there is probably an underestimation of the rate of death by sexual asphyxiation in Indian setup. We highlight the importance of positive interpretation of autoerotic death with regards to death scene circumstantial evidence, past history of lethal and non-lethal paraphilia, and autopsy findings in determining manner of death.

\section{Conclusion}

Based on the analysis of the death scene and autopsy findings in our case, we concluded that, rather than suicide or homicide, this was an accidental autoerotic asphyxiation caused by hanging. Case report supports the creation of complex sexual scenes by male subjects. In this case, consideration of the death scene is important in understanding the motivation and behavior of the young decedent. Finally, case report also raises the important issue of the relatively easy and rapid dissemination of paraphilia and pornography in our developing society which requires further systematic research as well as serious preventive interventions. People need to be informed about the risks of such activities and the danger of being unable to stop the asphyxial process before losing their consciousness.

\section{Acknowledgements}

This research did not receive any specific grant from funding agencies in the public, commercial, or not-forprofit sectors.

\section{Conflict of Interest}

The authors declared no conflicts of interest.

\section{References}

[1] World Health Organisation. International statistical classification of diseases and related health problems, $10^{\text {th }}$ revision. Geneva: World Health Organisation, 2016.

[2] American Psychiatric Association. Diagnostic and statistic manual of mental disorders. Washington DC: American Psychiatric Association; 1994

[3] Meyer JK. Paraphilias. In: Kaplan HI, Sadock BJ, editors. Comprehensive textbook of psychiatry. Baltimore: Williams \& Wilkins; 1995.

[4] Blanchard R, Hucker SJ. Age, transvestism, bondage, and concurrent paraphilic activities in 117 fatal cases of autoerotic asphyxia. The British Journal of Psychiatry. 1991; 159(3):3717. doi: $10.1192 /$ bjp.159.3.371

[5] Byard RW. Autoerotic death - characteristic features and diagnostic difficulties. Journal of Clinical Forensic Medicine. 1994; 1(2):71-8. doi: 10.1016/1353-1131(94)90003-5

[6] Tournel G, Hubert N, Rougé C, Hédouin V, Gosset D. Complete autoerotic asphyxiation. The American Journal of Forensic Medicine and Pathology. 2001; 22(2):180-3. doi: 10.1097/00000433-200106000-00014

[7] Hitchcock A, Start RD. Fatal traumatic asphyxia in a middle-aged man in association with entrapment associated hypoxyphilia. Journal of Clinical Forensic Medicine. 2005; 12(6):320-5. doi: 10.1016/j.jcfm.2005.05.010

[8] Focardi M, Gualco B, Norelli G. Accidental death in autoerotic maneuvers. The American Journal of Forensic Medicine and Pathology. 2008; 29(1):64-8. doi: 10.1097/ paf.0b013e3181651b79

[9] Bhardwaj DN, Rautji R, Sharma RK, Dogra TD. Suicide by a transvestite or sexual asphyxia. Medicine, Science and the Law. 2004; 44(2):173-5. doi: 10.1258/rsmmsl.44.2.173

[10] Sauvageau A, Racette S. Autoerotic deaths in the literature from 1954 to 2004: A review. Journal of Forensic Sciences. 2006; 51(1):140-6. doi: 10.1111/j.1556-4029.2005.00032.x

[11] Giono J. [Faust in the village (French)]. Paris: Edition Gallimard; 1928

[12] Byard RW, Hucker SJ, Hazelwood RR. A comparison of typical death scene features in cases of fatal male and female autoerotic asphyxia with a review of the literature. Forensic 
Science International. 1990; 48(2):113-21. doi: 10.1016/03790738(90)90103-6

[13] Behrendt N, Buhl N, Seidl S. The lethal paraphiliac syndrome: Accidental autoerotic deaths in four women and a review of the literature. International Journal of Legal Medicine. 2002; 116(3):148-52. doi: 10.1007/s00414-001-0271-x

[14] DiMaio D, DiMaio VJ. Forensic pathology. Boca Raton: CRC Press; 2001

[15] Gosink PD, Jumbelic MI. Autoerotic asphyxiation in a female. The American Journal of Forensic Medicine and Pathology. 2000; 21(2):114-8. doi: 10.1097/00000433-20000600000004

[16] Wesselius CL, Bally R. A male with autoerotic asphyxia syndrome. The American Journal of Forensic Medicine and Pathology. 1983; 4(4):341-6. doi: 10.1097/00000433198312000-00012

[17] Innala SM, Ernulf KE. Asphyxiophilia in Scandinavia. Archives of Sexual Behavior. 1989; 18(3):181-9. doi: 10.1007/ bf01543193

[18] Ober WB. The sticky end of frantisek Koczwara, composer of "The battle of Prague". The American Journal of Forensic Medicine and Pathology. 1984; 5(2):145-50. doi: 10.1097/00000433-198406000-00008

[19] De Coccola R, King P. The incredible Eskimo: Life among the barren land Eskimo. Surrey, BC: Hancock House; 1986.

[20] Anderson HR, Macnair RS, Ramsey JD. Deaths from abuse of volatile substances: A national epidemiological study. BMJ. 1985; 290(6464):304-7. doi: 10.1136/bmj.290.6464.304

[21] Breitmeier D, Mansouri F, Albrecht K, Böhm U, Tröger HD, Kleemann WJ. Accidental autoerotic deaths between 1978 and 1997. Forensic Science International. 2003; 137(1):41-4. doi: 10.1016/s0379-0738(03)00275-5

[22] Johnstone JM, Hunt AC, Ward EM. Plastic-bag asphyxia in adults. BMJ. 1960; 2(5214):1714-5. doi: 10.1136/ bmj.2.5214.1714

[23] Tournel G, Hubert N, Rougé C, Hédouin V, Gosset D. Complete autoerotic asphyxiation. The American Journal of Forensic Medicine and Pathology. 2001; 22(2):180-3. doi: 10.1097/00000433-200106000-00014

[24] Vennemann B, Pollak S. Death by hanging while watching violent pornographic videos on the Internet-suicide or accidental autoerotic death. International Journal of Legal Medicine. 2005; 120(2):110-4. doi: 10.1007/s00414-005-0016-3 